\title{
Race, Ethnicity, and the Future of Work ${ }^{1}$ \\ Pegah Moradi
}

\begin{abstract}
A thesis submitted in partial fulfillment of the requirements for the Degree of Bachelor of Arts with Honors as a College Scholar

Cornell University
\end{abstract}

December 2018

\author{
Under the advising of \\ Sergio Garcia-Rios, Government \\ Karen Levy, Information Science \\ Jamila Michener, Government
}

\footnotetext{
${ }^{1}$ All reproducible code and data for this study can be found at https://github.com/pegahmoradi/pegahmoradi.github.io/tree/master/automation_race
} 
Table of Contents

$\begin{array}{lr}\text { Abstract } & 3\end{array}$

$\begin{array}{lr}\text { Introduction } & 4\end{array}$

$\begin{array}{ll}\text { Race, Labor, and Automation: A History } & 7\end{array}$

$\begin{array}{ll}\text { How Work Created Whiteness } & 7\end{array}$

$\begin{array}{ll}\text { The First Machine Age } & 8\end{array}$

(1) What kind of work was automated? $\quad 9$

(2) How did automation affect employment? $\quad 12$

(a) Black Labor 13

(b) Chinese Immigration $\quad 15$

(c) Mexican Bracero Program 16

$\begin{array}{ll}\text { (3) How did workers react? } & 18\end{array}$

$\begin{array}{lr}\text { Automation Today: Trends and Frameworks } & 20\end{array}$

$\begin{array}{ll}\text { Definitions } & 20\end{array}$

$\begin{array}{ll}\text { Prevailing Frameworks } & 20\end{array}$

$\begin{array}{ll}\text { Data and Results } & 24\end{array}$

$\begin{array}{ll}\text { Limitations } & 30\end{array}$

$\begin{array}{ll}\text { Conclusion } & 32\end{array}$

$\begin{array}{ll}\text { Final Thoughts } & 33\end{array}$

$\begin{array}{ll}\text { Acknowledgements } & 35\end{array}$

$\begin{array}{ll}\text { References } & 36\end{array}$ 


\begin{abstract}
Leading up to and following the 2016 American presidential election, "White working class" employment and political agency has become particularly salient. A simultaneous discussion on the role of automation in unemployment complicates the political narrative; by one estimate, $47 \%$ of American jobs are at risk of computerization (Frey and Osborne, 2013). This study analyzes how occupational automation corresponds with racial and ethnic demographics within occupational groups from both a historical and contemporary perspective. I find that throughout American industrialization, non-White and immigrant workers shifted to low-wage, unskilled work because of the political and social limitations imposed upon these groups. In the context of today's AI-driven automation, I find that White workers are more heavily affected by automatability than other racial groups. Conversely, however, I found that the proportion of White workers in an occupation is negatively correlated with an occupation's automatability. I conclude with suggestions for a susceptibility-based approach to predicting employment outcomes from AI-driven automation.
\end{abstract}




\section{Introduction}

"And I mean, I wrote down some numbers that are incredible, but the numbers of manufacturing jobs that are lost, especially in the Rust Belt - and the Rust Belt is so incredible. But we're losing companies, it's - it's unbelievable, one after another, just one after another."

- Donald Trump, remarks at the Carrier factory in Indianapolis, Indiana on December 1, 2016.

On December 1, 2016, then President-Elect Donald Trump addressed crowds at the Carrier plant in Indianapolis after the air-conditioning company decided to keep up to 1,000 jobs in the United States instead of moving them to Mexico (Schwartz, 2016). The speech, which framed the Carrier decision as a result of Trump's win, continued the protectionist rhetoric of the Trump campaign, which was often coupled with anti-immigrant sentiment (Hoban, 2017).

Likewise, around the time of the 2016 election, popular media tended to narrativize work in terms of race as well: The simplified narratives of the vulnerable "White manufacturing worker" and the "service worker of color" seemed to become emblematic of a divided American working class. In one Huffington Post op-ed, commentator and writer John Paul Brammer notes that the narrative that Latinos are "the jobs Americans don't want to do" is pervasive on both sides of the political spectrum: He cites "Kelly Osbourne defending Latinos against Donald Trump on The View by saying if Latinos all left the country, Trump would have no one to clean his toilet," and "Ohio governor and Republican presidential candidate John Kasich saying he supports Latinos by tipping the maid at the hotel" as examples of this pervasive generalization (Brammer, 2015).

Trump seemingly attempted to win over Black voters when he famously asked at a campaign event in Dimondale, Michigan, "You're living in poverty, your schools are no good, you have no jobs, $58 \%$ of your youth is unemployed - What the hell do you have to lose?" (LoBianco \& Killough, 2016). And, more recently, President Trump’s press secretary Sarah Huckabee Sanders 
asserted that the Trump administration had created more jobs for Black workers than President Obama's, a false claim which she later corrected (Qiu, 2018).

This racialized strategy and the ensuing success of the Trump campaign likely fueled the barrage of post-election popular press naming the aggrieved "White working class" as the primary explanatory variable for Trump's win. One New York Times article connected Donald Trump's victories to areas experiencing major job loss, while The Washington Post's "Wonkblog" cited job loss and lowered wages for the "revenge" of the White working class during the election, notably mentioning, "[the] workers increasingly came to see trade deals as the culprit" (Porter, 2016; Tankersley, 2016).

A simultaneous and somewhat disparate discussion is taking place primarily among technologists and economists: These scholars pinpoint automation-namely a new wave of automation that is aided by the combined advances in artificial intelligence, big data, and robotics-as the driving force for current and impending unemployment. The most recognized of the literature on automation and employment comes from Frey and Osborne (2013) in an authoritative study that calculated automation probabilities for American occupations and determined that approximately $47 \%$ of U.S. jobs are "at risk of automation." Frey and Osborne (2013) and other studies of automation and employment tend to solely focus on technological capability as the predictor of future employment (see Autor, 2003).

While these two discussions of work and race have been relatively disjoint, they have, at times, converged. The Los Angeles Times columnist David Horsey began the connection of these two disjointed conversations on employment, arguing that "Robots, not immigrants, are taking American jobs" (2017). A recent study by Frey, Berger, \& Chen (2018) found that robot adoption in a given labor market was linked to significantly higher support for Donald Trump in 2016. The 
automation literature is thus beginning to analyze the changes in political response and national narrativization as a result of automation, but coverage continues to be minimal.

The automation literature remains particularly avoidant in discussing how non-technological factors affect potential employment outcomes due to automation. This study attempts to elucidate the importance of merging these two distinct narratives by describing the historical inseparability of race and labor, and then by quantitatively considering how different racial and ethnic groups are differently affected by their predicted occupational automatabilities in an AI-driven future. 


\section{Race, Labor, and Automation: A History}

Exploring the relationship between today's AI-driven automation and racial demographics requires an analysis of the history of race and labor throughout American history, from slave labor to immigrant labor to the segregation and stratification of labor today. In this section, I first explore how labor and race serve to create and reinforce one another. I then will consider a brief history of industrialization, automation, and race in the 19th- and early 20th-century United States. How Work Created Whiteness

In his seminal work The Wages of Whiteness, David Roediger (2007) asserts that changes in labor hierarchies reinforced racial hierarchies, leading to the emergence of a distinct "White working class." Historically, colonial- and revolutionary-era Americans conflated a lack of political freedom with slavery. Roediger (2007) describes some of the rhetorical ways in which early American political thinkers would use terms like "slavery" and "freeman" in the context of consenting to laws as opposed to bondage and labor, and cites Benjamin Franklin's 1770 definition of slavery as one that is inclusive of not just Black slavery, but also indentured servitude and apprenticeship. Franklin's definition of slavery was therefore deliberately raceless; it allowed for abstract ideas of tyranny, liberty, and freedom to concretize into a "physical reality that people were willing to suffer and die for" (Roediger, 2007, p. 29).

In the 18th and early 19 th century, White Americans were satisfied by simply existing in contrast to Black slaves. White work - like apprenticeship and indentured servitude - was visibly and semantically distinct from unfree Black labor until the late 19th century, when White workers became increasingly dependent on wage labor (Roediger, 2007). The formal similarity between Black and White workers-wage labor-thus served as the impetus for the creation and reinforcement of Whiteness (Roediger, 2007). As Roediger (2007) writes, one way for Whites to 
reconcile dependence on hireling wage labor was to differentiate their labor sharply from slave labor. Even the vocabulary of work was differentiated: After the increase of White wage labor, Black domestic workers began to be known as "the help" or "hired hands," and for white industrial workers the Dutch term "boss" was used instead of "master," despite the the translations being identical (Roediger, 2007). Ultimately, following emancipation, White Americans could no longer derive "satisfaction" from defining themselves as being non-slaves and non-Blacks, in some ways suggesting that the greater strides made towards formal labor equality, the more Whiteness had to distinguish and elevate itself (Roediger, 2007).

The construction of Whiteness in terms of labor is perhaps best demonstrated by the "Whitening" of Irish immigrants to the United States. During the antebellum period, Black and Irish workers were at first socioeconomically indistinguishable: both groups lived in the same overcrowded slums, did the same kinds of difficult, low-paying jobs ("especially in domestic service and the transportation industry"), and were similarly vilified by native-born White Americans (Roediger, 2007, p. 134). As Noel Ignatiev writes in How the Irish Became White, being Immigrants, the Irish in the early 19 th century began to differentiate themselves as White in order to obtain naturalized citizenship along with other legal benefits and social powers, and were able to do so largely through their political leverage as a distinct bloc of potential voters (1995).

\section{The First Machine Age}

Many contemporary narratives - both fictional and non-fictional - fear a future in which today's artificial intelligence and robotics technologies are completely replacing human labor. Op-eds like a February 2018 piece in The Guardian titled "Robots will take our jobs. We'd better plan now, before it's too late,” or one from December 2017 titled “Will Robots Take our Children’s Jobs?" in The New York Times paint a picture of a highly vulnerable workforce that will experience 
dystopian outcomes if social or political action is not taken to curb the effects of automation.

Though scholars differ as to what these outcomes will realistically be, the new wave of automation spurred by a combination of artificial intelligence, big data, and robotics (which I will refer to as AI-driven automation throughout this paper) is reminiscent of American industrialization in the late-19th century. In their authoritative work on AI-driven economies, Brynjolfsson and McAfee suggest that digital technologies have jump-started a "second machine age":

Now comes the second machine age. Computers and other digital advances are doing for mental power-the ability to use our brains to understand and shape our environments-what the steam engine and its descendants did for muscle power. They're allowing us to blow past previous limitations and taking us into new territory. (Brynjolfsson \& McAfee, 2016, p. 19)

While the technologies of the digital age are of course vastly different from those of the industrial revolution, the industrialization period still had similarly high stakes in dramatically shifting societal development. What lessons, then, can be learned from the first major wave of automation in the United States? In this subsection, I will examine three questions on industrialization in order to glean some insight into how the second machine age may alter outcomes for different groups of workers today. First, I will consider what kind of work was automated, or what technologies replaced what tasks and altered what skills. Second, I will explore how automation affected employment, both generally and across different demographics, focusing on three historical vignettes: slavery and Black labor, Chinese immigration, and the Mexican Bracero Program. Lastly, I will review some of the literature on how workers responded to automation during the first industrial revolution.

(1) What kind of work was automated?

Driven by the development of James Watt's steam engine, the American industrial revolution (1790-1930) notably made large-scale energy production possible and, as a result, set off a chain of innovation and rapid economic growth throughout many areas of the United States 
(Cowan, 1997). The steam engine not only reduced the amount of manual labor needed to power mills and other machinery, but it also allowed factories to be built in cities rather than attached to rivers and in the countryside (Cowan, 1997).

Though artisans made up a small proportion of the workforce in the early 19 th century, the unique social circumstances of artisan workers were crucial to urban industrialization in the United States, and as a result these workers bore many of the costs of industrialization (Cowan, 1997). Colonial artisans like carpenters worked under a master-apprentice system where masters maintained shops connected to the home and oversaw nearly all of the steps in the manufacturing process, from purchasing the raw materials, to supervising apprentices and journeymen, to purchasing tools made by other artisans (Cowan, 1997). The end of British mercantilist policy meant that American colonies who were previously disincentivized from improving artisanal productivity and encouraged to provide resources for manufacturing in Great Britain could now invest in more productive manufacturing (Cowan, 1997). This policy change, coupled with booming population growth around the globe and increased demand for manufactured goods led to the proliferation of improved tools for artisan masters (Cowan, 1997). The proliferation of the steam-engine (and later, electric power) allowed for the automation of the use of these tools, such as automatic saws and power sanders in the case of carpenters (Cowan, 1997).

Artisans initially welcomed the use of these tools as they allowed for lower production cost and greater economies of scale, allowing masters to lay off journeymen who no longer had to laboriously use manual tools (Cowan, 1997). However, as improved mechanical tools deskilled the work of masters, they were increasingly replaced by unskilled or semi-skilled laborers who could simply do redundant operational work on the factory floor. As Ruth Schwartz Cowan writes in $A$ Social History of American Technology, 
What had once taken days of painstaking, careful work for a master to produce could now be run up in a few minutes by a thirteen-year old operating a machine. If the average carpenter had once known how to carve a complex molding out of a length of wood, he now only needed to know how to miter factory-carved pieces together at the corners - and what was there to be proud of in that? (p. 184)

In the case of American artisans, then, automation deskilled previously skilled work that was costly, repetitive, and impersonal: In the United States, wealthy builders began to pay for the services of carpenters with little care or respect for the formalities of the guild system, like where the journeymen involved in a construction were trained (Cowan, 1997).

In the context of farming, on the other hand, mechanization depended on the crop. Cowan (1997) describes tobacco as an example of one of the most labor-intensive crops to cultivate and harvest; no particularly effective mechanization process was found for it until the 1960s. The majority of American farmers (particularly in the Midwest) during the 19th century, however, were wheat growers, and nearly all steps of wheat production had been effectively mechanized by 1880 (Cowan, 1997). Much like in the artisan manufacturing context, different farmers experienced different outcomes and a gradual shifting of attitudes regarding production. As Cowan (1997) argues, wealthier for-profit farms that could afford automated equipment benefitted from lower labor costs, and farms that could not afford the equipment were often sold to those that could. Even wealthy farmers who could afford new equipment experienced some harms of this mechanization: Increased productivity lead to increased supply and therefore lower prices (Cowan, 1997). Whereas in 1866 a bushel of wheat would cost $\$ 2.06$, by 1874 the price had dropped to $\$ 0.95$ per bushel (Cowan, 1997).

Unlike the automation of skilled artisan labor, farming was mechanized largely due to issues of demand and scale rather than skill. Though it is perhaps unclear whether a cause or effect of industrialization, the global population boom and growth of the textile industry in Europe ultimately made the demand for cheap cash crops skyrocket. Although much of the farmwork that 
was automated was unskilled labor that needed little training, the automated work of both farm laborers and artisans was typically repetitive and predictable, and tended to rely on manual rather than cognitive skills.

\section{(2) How did automation affect employment?}

Although the American industrialization period brought about the displacement of many farm workers and the deskilling of artisanal workers, the period is often cited as an example of scale or productivity effects outweighing substitution or displacement effects (Acemoglu \& Restrepo, 2017; see Vardi, 2017). In other words, the innovation and expansion spurred by cheaper cost of production outweighs the effects of labor being replaced by technology (Autor, 2015).

In the case of artisans-turned-factory workers, the massive demand for manufactured products lead to a correspondingly massive demand for laborers who would operate the machinery in these industrialized factories. Cowan recounts that of all 10 million nonfarm manual workers in the U.S. in 1900, one third were unskilled "operatives and kindred workers," and another third were considered simply as "laborers" (1997, p. 187). Both groups of workers were likely largely unskilled, meaning that their labor could be easily replaced with little loss to "the quality or to the quantity of what is being produced" (Cowan, 1997, p. 179). These low-wage workers, referred to as "factory hands" or, more derogatorily, "wage slaves," engaged in what Cowen refers to as "repetitive, dangerous, oppressive, dead-end, low-paying, insecure jobs, the jobs that had been created when the work of traditional craftsmen had been subdivided, automated, and mechanized” (1997, p. 188).

While this work was initially taken up by the previous craftsmen and journeymen who were typically native-born White Americans (typically of Germanic and British origin), the demand for labor began to outpace the supply of these workers, and competition between factories meant low wages and poor working conditions (Cowan, 1997). As a result, in most of the United States, the 
demand for this labor was met with the labor of immigrants or non-White Americans. Here, geography and sector also begin to play a role in where different demographics worked. As Cowan recounts,

[T]he French Canadians and the Irish dominated the textile mills of Massachusetts; African American men and women sweated in the steam laundries of almost every major city; Jewish women were employed as cigar molders in Pennsylvania; Polish men were butchering cows and Polish women were stuffing sausages for the Chicago meat-packers; Italian men were making cans in New York; Mexican women were packing tomatoes in California.... In factories from one coast to another, the skilled and unskilled workers could thus be distinguished from one another not just by the wages they were paid but also by the color of their skin and the country of their birth. (p. 188-189)

The stratification between native White wage laborers and non-White and immigrant wage

laborers thus comes to light and is reminiscent of Roediger's arguments on the construction of

Whiteness. How, then, did automation and industrialization affect work for these varying

demographics? For the remainder of this subsection, I will focus on three historical vignettes:

Slavery and Black labor, Chinese immigrant labor, and the Mexican Bracero Program.

(a) Black Labor

In another quintessential example of scale effects outweighing substitution effects, the invention of the cotton gin in the 1790s served to deskill one important task in particular (picking cotton fiber from its seed) while simultaneously dramatically increasing cotton production, thus increasing demand for labor to plant and pick cotton for the booming national and international demand (Trotter, 2000). As Trotter writes, "More so than earlier agricultural practices, the cotton gin placed African Americans' labor power, rather than their technical knowledge, at the center of agricultural production" (2000, p. 20). Plantation labor was expanding due to more efficient cotton production, but there was also the beginning of some industrialized work in the south, or what Trotter calls "growing use of unfree Black labor in rural- and urban-based industries" (2000, p. 20). 
Though by the end of the industrialization period, Black men and women both predominantly worked in agriculture, mining, domestic service, and other types of manual work, the majority of Black men in several rustbelt and midwestern cities like Chicago and Detroit worked in industry (Jones, 1998). Black labor in industrializing cities was often relegated to the most menial, drudging tasks. Jones (1998) notes that "Blacks of both sexes remained at the lowest levels of the labor force, effectively barred in many instances from achieving semi-skilled positions" (Jones, 1998, p. 306). Black workers regardless of gender thus had to take jobs in the "three Ds," or dull, dirty, and dangerous work that was dismissed by White workers who could find better employment elsewhere. Black women were often relegated to manual field and kitchen labor in the south and hand laundry work in industrial cities, while White women were able to work machines in southern factories or work secretarial jobs in the factory offices (Jones, 1998).

As previously mentioned, though industrialization had led to booming demand for low-skill labor, Black laborers in industrial contexts often either lacked any kind of upward mobility in their work or were barred from being hired at all. While Black workers were disproportionately represented in some kinds of jobs, Jones argues that Black industrial workers did not have employment "niches" in the same way that immigrant laborers did during the same period of time, and as such lacked the same potential upward mobility and capability for collective action (1998). Moreover, hiring a Black worker over a White one - or placing a Black worker in a position of superiority over a White worker - was seen as a moral failing (Jones, 1998). Likewise, low-wage Black labor was often used as a means of wage discipline for White workers, and many employers saw Black workers as being predisposed to be better at performing the more difficult and dirty tasks at factories (Jones, 1998). 


\section{(b) Chinese Immigration}

The same trends towards more difficult, gruelling work being given to non-White laborers in the 19th and early 20th centuries is present amongst Chinese laborers. The first major wave of Chinese immigration to the United States came during the gold rush in the mid-19th century, but as profits from gold decreased, Chinese laborers began to look for other kinds of work (Takaki, 1989). As with Black labor, Chinese workers tended to do jobs that were dull, dirty, or dangerous and unwanted by White workers. Most famously, the mid-century railroad construction projects hired large numbers Chinese workers: by 1867, 90 percent of the Central Pacific Railroad's workforce was Chinese, and the use of Chinese labor was encouraged due to a labor shortage following the Civil War (Takaki, 1989).

The response to the wide Chinese labor by White capitalists was two-fold: Reliance on Chinese labor was seen as a way to elevate the status of White workers whose skills were considered above "three Ds" labor (Takaki, 1989). One railroad builder, Charles Crocker, described how employing Chinese workers allowed White workers to become capitalists:

\footnotetext{
I think that every White man who is intelligent and able to work... who has the capacity of being something else by the presence of Chinese labor easier than he could without it.... After we got Chinamen to work, we took the more intelligent of the White laborers and made foremen of them. Several of them who never expected, never had a dream that they were going to be anything but shovelers of dirt, hewers of wood and drawers of water are now respectable farmers, owning farms. They got a start by controlling Chinese labor on our railroad. (1876)
}

Likewise, Chinese labor was used as a form of wage discipline, much like Black laborers were used in industry (Takaki, 1989). Chinese workers were used as a bargaining chip in order to hold down the wages of both White and Chinese workers, and as a result faced animus from predominantly White labor unions, such as the 1867 Secret Order of the Knights of St. Crispin, established in response to "labor-eliminating machines and low wages" (Takaki, 1989, p. 96). Ultimately, as Takaki (1989) notes, “Capital used Chinese laborers as a transnational industrial reserve army to weigh 
down White workers during periods of economic expansion and to hold White labor in check during periods of overproduction” (p. 29).

The result of the racialized wage discipline was, expectedly, racial antagonism that helped to reinforce a dominantly White employer class and a racialized, "divided working class" (Takaki, 1989, p. 29). As a result of this antagonism, Chinese workers had few employment options once the major railroad projects were completed, and returned to the Chinatowns of major cities to rely on the "ethnic economy," or the employment "niches" that Jones (1998) references, like Chinese laundries and restaurants (Takaki, 1989). Continuing low wages and a prevailing view that Chinese immigrants would not be able to assimilate into American culture preceded the Chinese Exclusion Act, which prohibited Chinese laborers from immigrating, and was later expanded to include all Chinese individuals (Takaki, 1989). As Takaki (1989) notes,

In fact there was very little objective basis for the Congress to be worried about Chinese immigrants as a threat to White labor. The Chinese constituted a mere .002 percent of the U.S population in 1880 .... Congress was responding to the stressful reality of class tensions and conflict within White society during an era of economic crisis. (p. 110)

In the context of the Chinese, then, changes in labor patterns affected racial structure in Roediger's terms, and then in turn influenced immigration policy, further affecting the labor market long-term.

\section{(c) Mexican Bracero Program}

Though occurring after the industrialization period, the Mexican Farm Labor Agreements are demonstrative of further connections between race and labor, particularly in the American southwest. The Mexican Farm Labor Agreements were a series of bilateral agreements between the US and Mexico, mainly starting with the MFLA of 1942 (Scruggs, 1960). These agreements allowed for millions of men from Mexico to enter the U.S. as short-term agricultural laborers, mainly to fill labor shortages brought about by World War II, similar to the use of Chinese labor to fill labor 
shortages following the Civil War. The program was not without backlash: Some organized labor leaders in the US saw it as a way to keep wages low for all agricultural workers, while some farmers saw it as a means of exercising bureaucratic controls over US farmers, as many of these contracts had minimum wage agreements (Scruggs, 1960).

In the final years of this industrialization period, more native-born American laborers were migrating to doing seasonal agricultural work. Thanks to cheap automobiles, the "victims of technology and soil exhaustion” were able to escape the dust bowl attempt to find work in agriculture (Scruggs, 1960, p. 140). Once the United States began involvement in World War II, however, many White American laborers migrated to war plants and farmers were once again in need of more laborers and ultimately lobby federal and state governments for permission to bring in thousands of Mexican laborers (Scruggs, 1960). Mexican workers already in the U.S. were unable to work in the slightly better conditions of the industrial war plants with their native-born counterparts due to restrictions on employing immigrants in war industries (Scruggs, 1960). Much like the Chinese immigration context, immigrant and non-White workers during this time period once again faced limitations on how to respond to employment changes and economic shocks due to legal and social barriers.

In sum, these three historical vignettes can be generalized into three main trends: (1) Non-White and immigrant labor generally shifted into work that was low-skill or deskilled, as with Black industrial workers (Cowan, 1997); (2) these laborers tended to work jobs in the "three Ds," or dull, dirty, and dangerous work, with Chinese workers being a predominant example (Brynjolfsson \& McAfee, 2016); and lastly, (3) the agency of their labor was more susceptible to control by the state, as demonstrated by the Chinese Exclusion act and the limitations on Mexican braceros, who were legally prevented from working in domestic wartime industry. 


\section{(3) How did workers react?}

American workers reacted to and resisted aspects of industrialization, often taking the shape of attempting to organize or revolt (Cowan, 1997). The years following the falling prices of agricultural products were met with the Grange, the Farmers Alliance, the emergence of the populist political party, and the lobbying of federal and state governments to enact economic policy that would benefit farmers, like enacting protective tariffs (Cowan, 1997). The journeymen whose work was becoming increasingly precarious during the industrialization period began to organize with masters into guilds, which in turn worked to mainly benefit the interests of masters (Cowan, 1997). When these efforts failed, journeymen carpenters unsuccessfully went on strike 35 times (Cowan, 1997). After most artisanal work had transitioned into factory work, unskilled factory workers attempted to join trade unions, but were faced with opposition by the unions themselves, which were actively antagonistic towards these workers perceived to be "a foreigner, a woman, a barbarian, or a scab: someone who was being brought into the workplace to cut wages, break a strike, or steal a job” (Cassedy, 1997; Cowan, 1997, p. 191).

At first, unskilled workers sought individual solutions to the lack of worker protections, like taking vacation by feigning sickness, quickly changing factory jobs to alleviate boredom (and thus leading to high turnover rates in factories), or deliberately slowing and sabotaging production (Cowan, 1997). Workers would ostracize those who perhaps produced too much too quickly, hiding materials, or temporarily breaking machines (Cowan, 1997). Industrial unions eventually formalized the qualms of workers into collective bargaining, but not until the later decades of the industrialization period, and they notably often discriminated against non-White workers (Cowan, 1997). 


\section{Automation Today: Trends and Frameworks}

\section{Definitions}

In order to distinguish between technological capability for replacing work and social, political, and economic likelihood of job replacement, I will draw semantic distinctions between these two concepts. For the purposes of this analysis, I will use the term automatability to refer to the extent to which a task can be accomplished by "adapting currently demonstrated technology" (“Automation Potential and Wages for US Jobs," 2018), and susceptibility to automation (or proneness to automation) as a variable that captures both technological capability and the social context of the task and occupation to measure the likelihood of replacement due to automation. For the purposes of referencing the results of Frey and Osborne (2013), I will use their terminology of the probability of computerization to refer to predicted automatability.

\section{Prevailing Frameworks}

Much of the literature on workplace automation makes predictions principally based on automatability, or the technological capabilities of workplace automation. At the cusp of the computer age, but prior to recent developments in artificial intelligence and big data, the influential task-biased model of technological change proposed by Autor, Levy, \& Murnane (2003) was the paradigmatic view of automatability. Autor et al. (2003) argue that prior to the computer age, automating physical and routine tasks would create complementary clerical, cognitive tasks in which humans had a comparative advantage. Computing power, however, altered the standards for automatability, as seen in Figure 1. This two-factor model is based off of the finding that technology ("computer capital") substitutes workers in both "cognitive and manual tasks that can be accomplished by following explicit rules," (i.e. that are abstractable and programmable), which the authors label as "routine" (Autor et al., 2003). Repeatedly adding and subtracting a set of numbers, 
for instance, is a routine cognitive task, while inserting screws into identical slots on identical pieces of plywood is a routine manual task under this dichotomy.

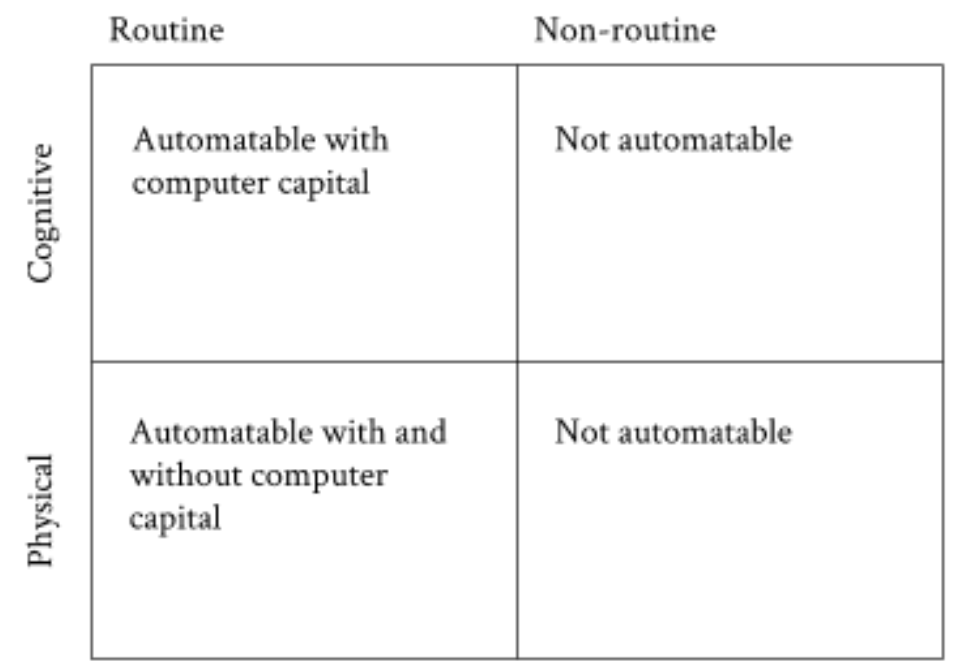

Figure 1. A heuristic for automatability based on Autor et al. (2003).

Combined advances in artificial intelligence, big data, and robotics have complicated this seminal model, allowing for greater automation of non-routine cognitive and physical tasks. Many tasks previously thought to be particularly non-routine are increasingly becoming converted into abstractable, well-defined problems aided by the availability of large and complex datasets (Frey \& Osborne, 2013). For instance, though Autor et al. explicitly mentioned truck driving as a manual non-routine task in their 2003 work, long-haul transport is expected to be an early adopter of driverless technology, and several companies have set goals to develop fully autonomous vehicles within the next half-decade (Muoio, 2017; Viscelli, 2018). 


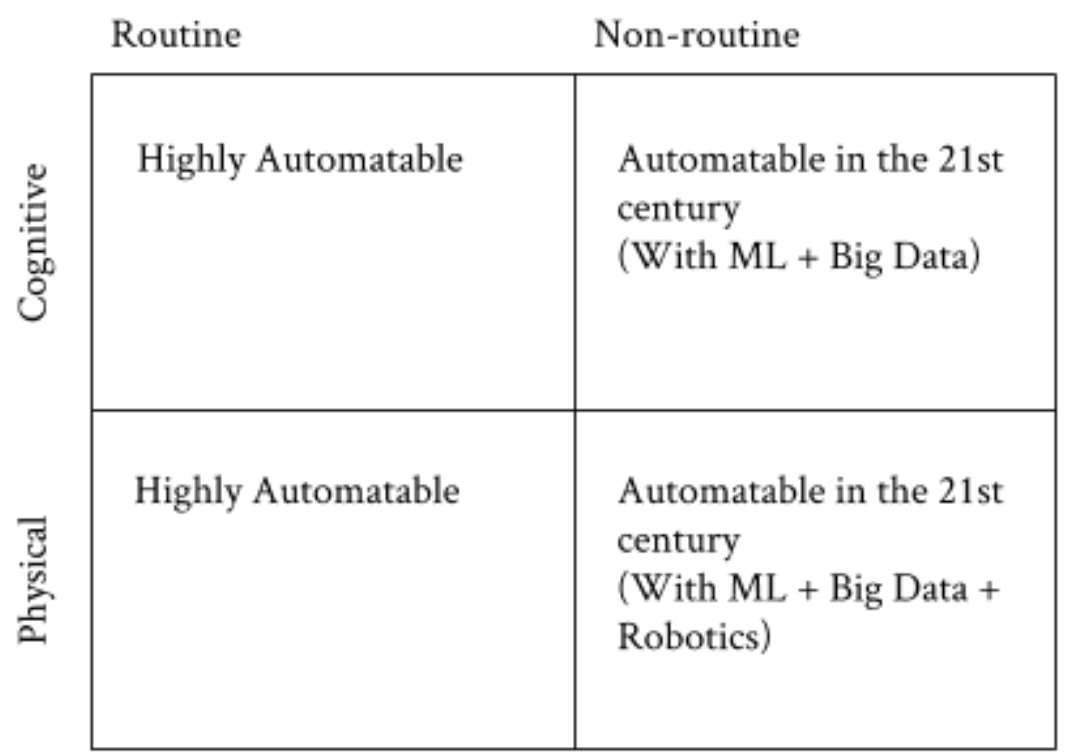

Figure 2. A heuristic for automatability in the 21st century.

As a result, developing a model for predicting automatability now requires a periodic audit of technological capability. This analysis in particular relies on the automatability predictions of Frey and Osborne (2013), based upon three primary "engineering bottlenecks": perception and manipulation, creative intelligence, and social intelligence. Frey and Osborne then selected measurable variables that characterized these three bottlenecks, as demonstrated in Table 1. Although the majority of research on employment and automation focuses primarily on technological capability, some recent efforts have been made to quantify the effect of automation on employment and wages while accounting for factors such as adjustments in other areas of the economy that can absorb freed up labor or simply the cost of labor vs. technological capital in certain sectors (Acemoglu \& Restrepo, 2017). Acemoglu \& Restrepo (2017) considered these factors when developing a model for predicting the employment and wage effects of automation, finding "large and robust negative effects of robots on employment and wages" (p. 36), but the broader literature is still lacking in the consideration of social and political factors involved in predicting employment and wage outcomes. 
Table 1. O*NET variables that serve as indicators of bottlenecks to computerisation, from

Frey \& Osborne (2013, p. 31).

\begin{tabular}{|c|c|c|}
\hline $\begin{array}{l}\text { Computerisation } \\
\text { bottleneck }\end{array}$ & O*NET Variable & $\mathrm{O} *$ NET Description \\
\hline \multirow[t]{3}{*}{$\begin{array}{l}\text { Perception } \\
\text { and } \\
\text { Manipulation }\end{array}$} & $\begin{array}{l}\text { Finger } \\
\text { Dexterity }\end{array}$ & $\begin{array}{l}\text { The ability to make precisely coordinated movements of } \\
\text { the fingers of one or both hands to grasp, manipulate, or } \\
\text { assemble very small objects. }\end{array}$ \\
\hline & $\begin{array}{l}\text { Manual } \\
\text { Dexterity }\end{array}$ & $\begin{array}{l}\text { The ability to quickly move your hand, your hand together } \\
\text { with your arm, or your two hands to grasp, manipulate, or } \\
\text { assemble objects. }\end{array}$ \\
\hline & $\begin{array}{l}\text { Cramped Work Space, } \\
\text { Awkward Positions }\end{array}$ & $\begin{array}{l}\text { How often does this job require working in cramped work } \\
\text { spaces that requires getting into awkward positions? }\end{array}$ \\
\hline \multirow[t]{2}{*}{$\begin{array}{l}\text { Creative } \\
\text { Intelligence }\end{array}$} & Originality & $\begin{array}{l}\text { The ability to come up with unusual or clever ideas about } \\
\text { a given topic or situation, or to develop creative ways to } \\
\text { solve a problem. }\end{array}$ \\
\hline & Fine Arts & $\begin{array}{l}\text { Knowledge of theory and techniques required to compose, } \\
\text { produce, and perform works of music, dance, visual arts, } \\
\text { drama, and sculpture. }\end{array}$ \\
\hline \multirow[t]{4}{*}{$\begin{array}{l}\text { Social } \\
\text { Intelligence }\end{array}$} & $\begin{array}{l}\text { Social } \\
\text { Perceptiveness }\end{array}$ & $\begin{array}{l}\text { Being aware of others' reactions and understanding why } \\
\text { they react as they do. }\end{array}$ \\
\hline & Negotiation & $\begin{array}{l}\text { Bringing others together and trying to reconcile } \\
\text { differences. }\end{array}$ \\
\hline & Persuasion & Persuading others to change their minds or behavior. \\
\hline & $\begin{array}{l}\text { Assisting and Caring for } \\
\text { Others }\end{array}$ & $\begin{array}{l}\text { Providing personal assistance, medical attention, emo- } \\
\text { tional support, or other personal care to others such as } \\
\text { coworkers, customers, or patients. }\end{array}$ \\
\hline
\end{tabular}




\section{Data and Results}

In order to begin to add cognizance of social and political context to existing predictions of automation employment, I will build on the existing automatability-focused literature by quantitatively considering who the affected workers are. In other words: What races and ethnicities are more likely to be affected by automation under existing models? To answer this question, I will consider the demographic makeup of American occupations alongside their respective predicted automatability in order to explore which racial and ethnic groups are most affected by automatability.

The occupational demographic data for this analysis was taken from the Bureau of Labor Statistics (BLS) Labor Force Statistics from the 2016 Current Population Survey, a monthly survey of employment patterns often referred to as the Household Survey. The particular dataset used in this paper was the annual averages of employed persons by detailed occupation, sex, race, and Hispanic or Latino ethnicity. BLS reports the the number of workers in an occupation alongside the percentage of workers who report themselves as Asian, Black, and Hispanic/Latino. The percentage of White workers is determined from subtracting the percentages of Asian and Black workers from 100. (Hispanic/Latino workers can be of any race and are therefore not included in the calculation.) This data was then aligned with the computerisation probabilities determined by Frey and Osborne (2013) by occupation. As previously mentioned, Frey and Osborne considered "Perception and Manipulation," "Creative Intelligence," and "Social Intelligence” as three engineering bottlenecks affecting automatability. The degree to which an occupation required skills in these three categories corresponded to the probability that the occupation would be computerized.

Because the occupational data from Frey and Osborne was based on the O*NET categorizations and the data from BLS was classified according to the Standard Occupational 
Classification (SOC), the SOC codes provided in the Frey and Osborne data were used to match the data sets. Notably, because this study could only consider the occupations that overlapped between the Frey and Osborne set and the SOC dataset, the occupations analyzed were fewer in number than the entire set of occupations for which the BLS provides demographic data. Furthermore, BLS does not report demographic data for occupations with fewer than 50,000 employees, and as such the dataset here contains only occupations with at least 50,000 workers.

After wrangling the data, some exploratory analysis was done on computerization and the proportions of certain demographics in a given population and loess smoothing was applied, as seen in Figure 3. Because of the large discrepancy between the proportion of White workers and minority workers in each occupation, minority workers were also considered independently, as seen in Figure 4.

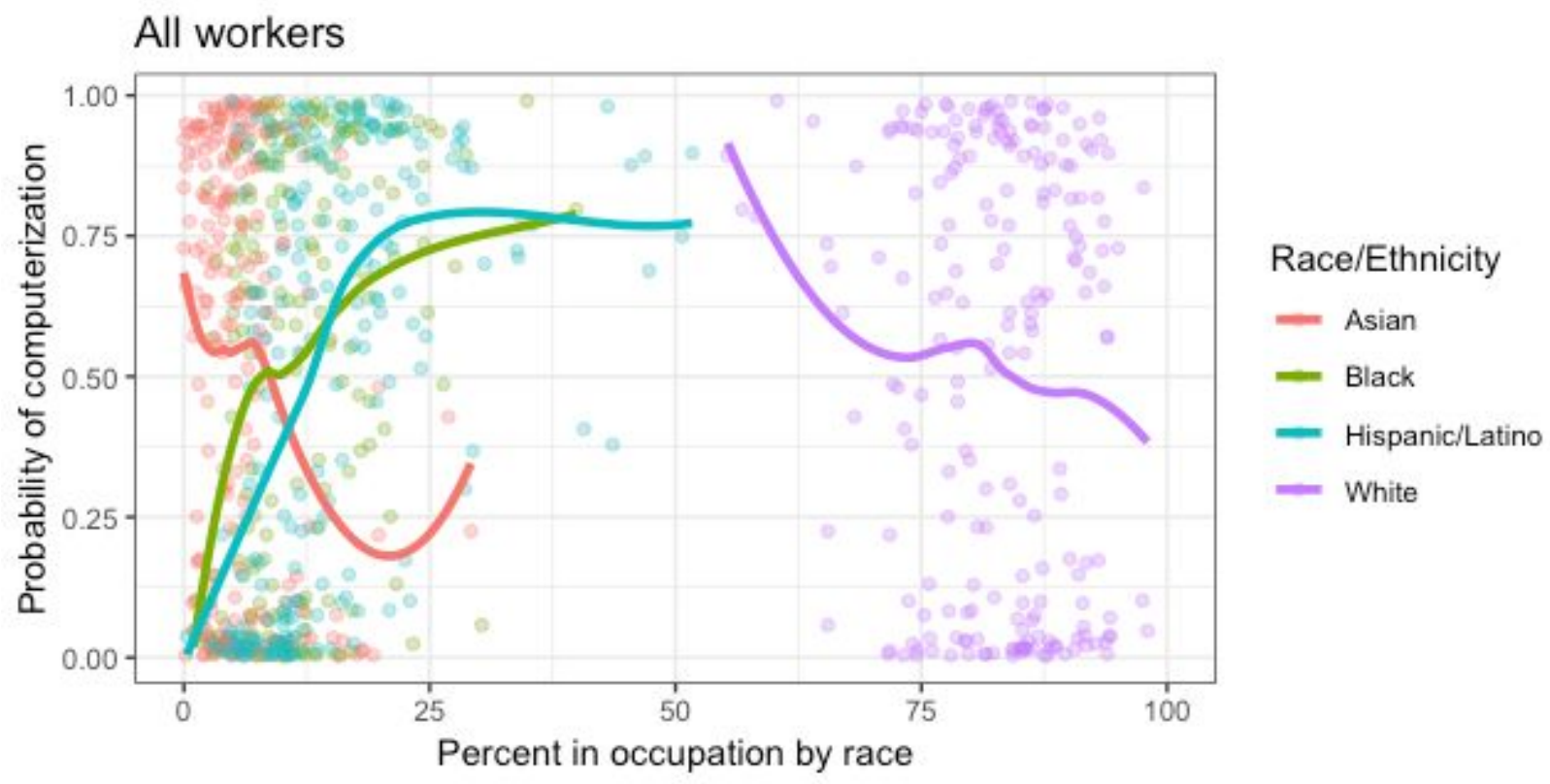

Figure 3. Exploratory analysis of probability of computerization based on intra-occupational representation 


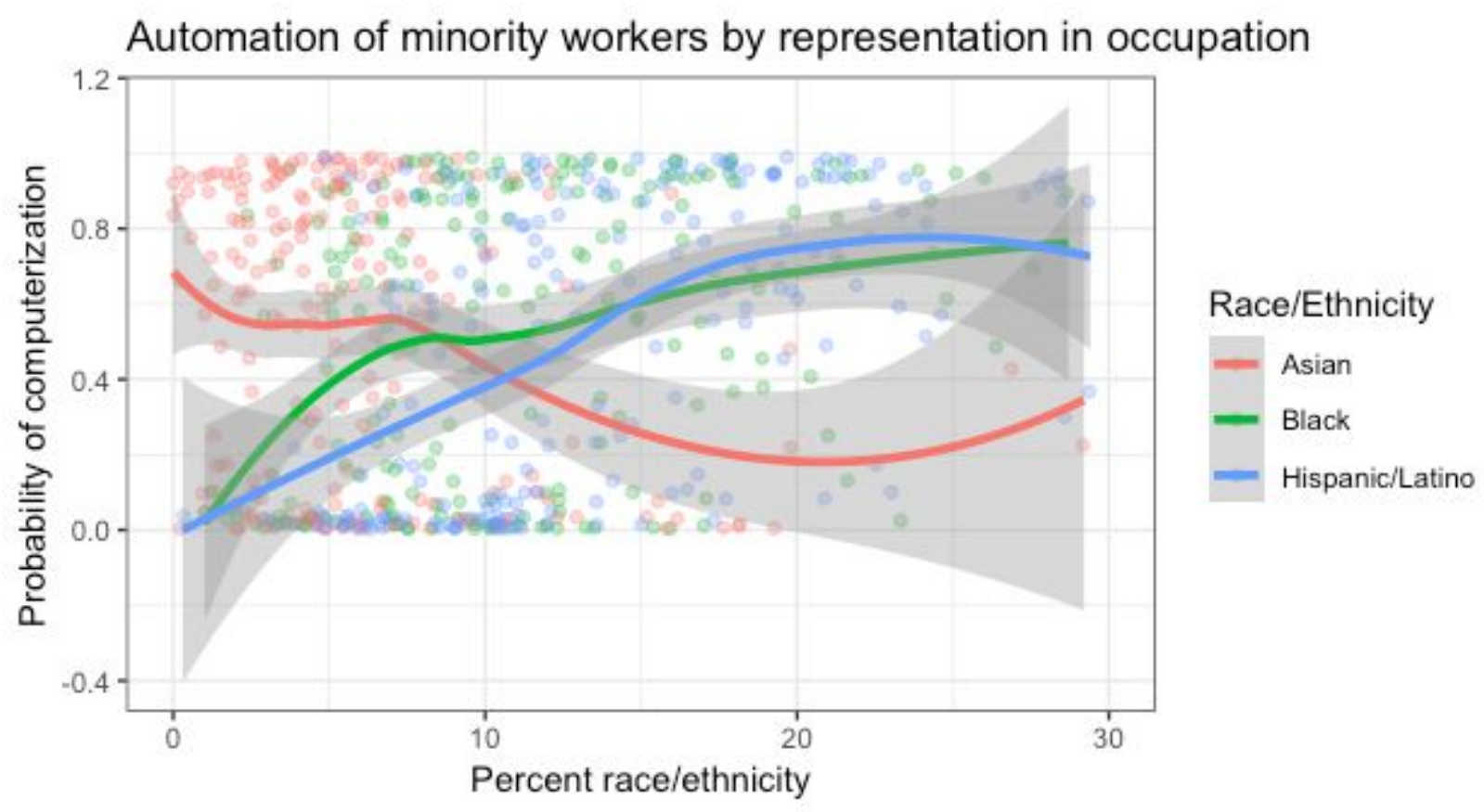

Figure 4. Exploratory analysis of probability of computerization for non-White and Hispanic/Latino workers.

Automation of white workers by representation in occupation

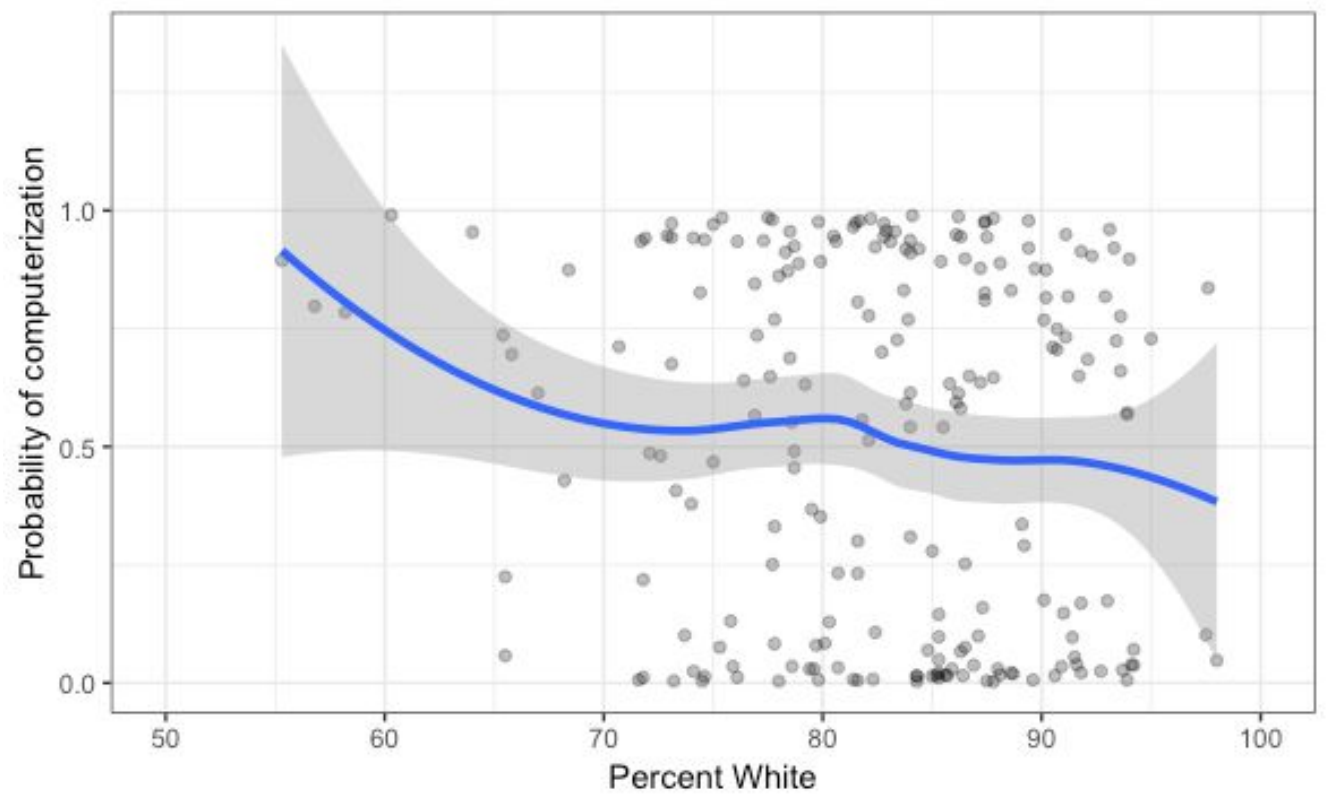

Figure 5. Exploratory analysis of probability of computerization for by intra-occupational representation of White workers. 
Because the BLS only reports demographic data by proportion rather than by population, estimates of the number of workers were generated by multiplying the proportions of individuals with the total number of people employed in an occupation and rounding down to generate a natural number. The probabilities of computerization were transformed into a categorical variable by creating bins of size 0.1 (from $0.0-0.9$ ), inclusive of the lower bound. Jitter was added to the resulting values to mitigate the effects of categorizing the probabilities. The counts of workers in each automatability group by race is graphically shown in Figure 6. The general U-shaped curve suggests labor polarization trends as proposed by Autor (2015).

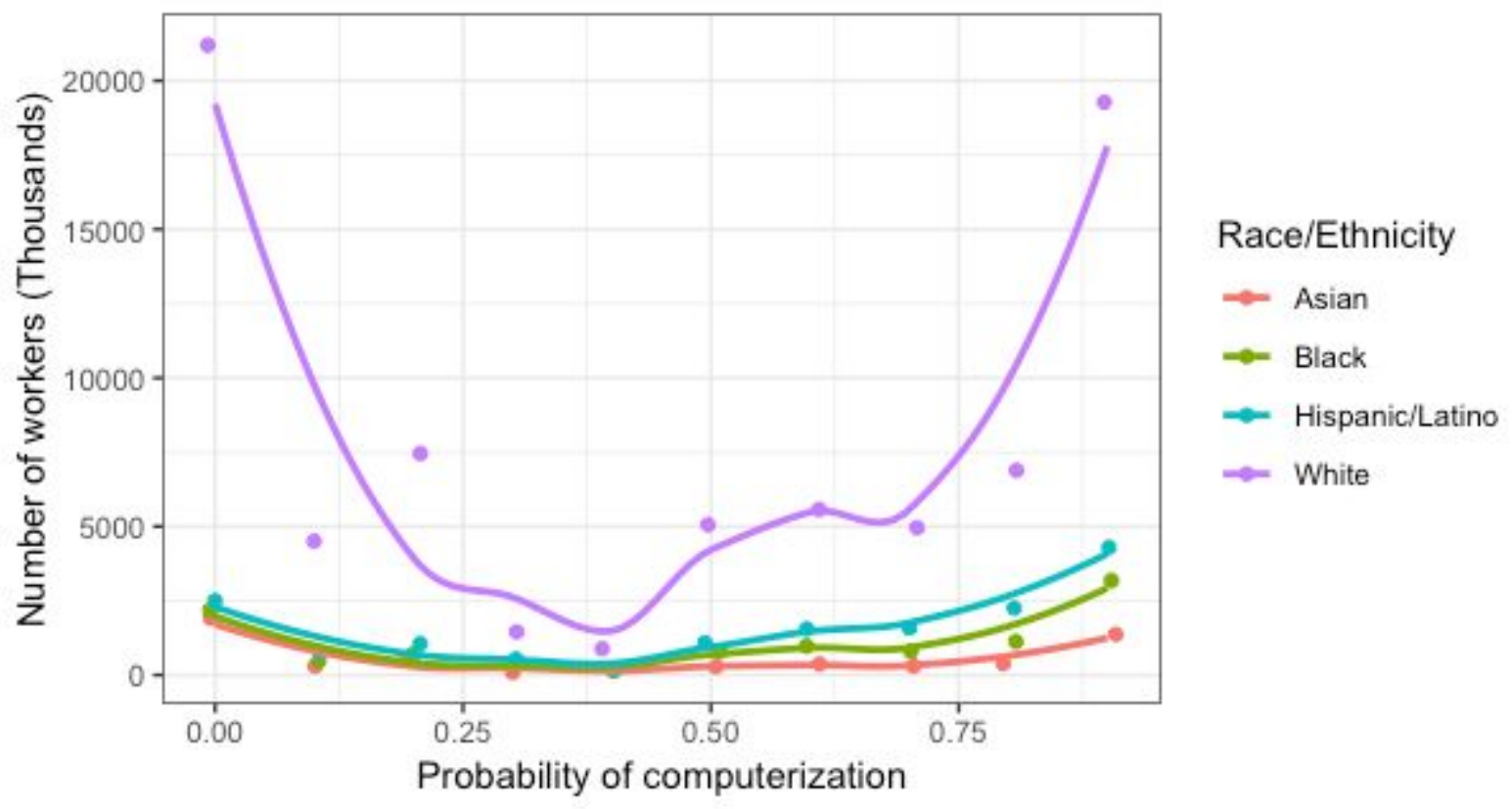

Figure 6. Number of workers in each automatability group by race and ethnicity.

In order to determine the total effect of computerization on each racial group, an Effect Factor $(\epsilon)$ was created using the following formula:

$$
\epsilon_{\text {occupation }}=\operatorname{Pr}(\text { Computerization }) \times n_{\text {group }}
$$

where $n_{\text {group }}$ is the number of individuals in a given demographic group. The aggregate effect factor for each race $(\delta)$ was then: 


$$
\delta_{\text {group }}=\text { proportion }_{\text {group }} \times \sum_{\text {occupations }}\left\{\operatorname{Pr}(\text { automation } \mid \text { occupation }) \times n_{\text {group }}\right\}
$$

The resulting $\delta$ values were considered for each demographic group. In order to further consider the effects of automation on each racial group individually, the $\delta$ values were scaled by the proportion of the total employed population each demographic group held. Accounting for proportion, White workers are disproportionately affected by automatability under the Frey \& Osborne (2013) prediction, as demonstrated in Figure 7. Comparing the $\delta$ values suggests that White workers are disproportionately affected by computerization even when accounting for the larger population of White workers in the American workforce. Hispanic/Latino workers have the second-highest effect, followed by Black and Asian workers.

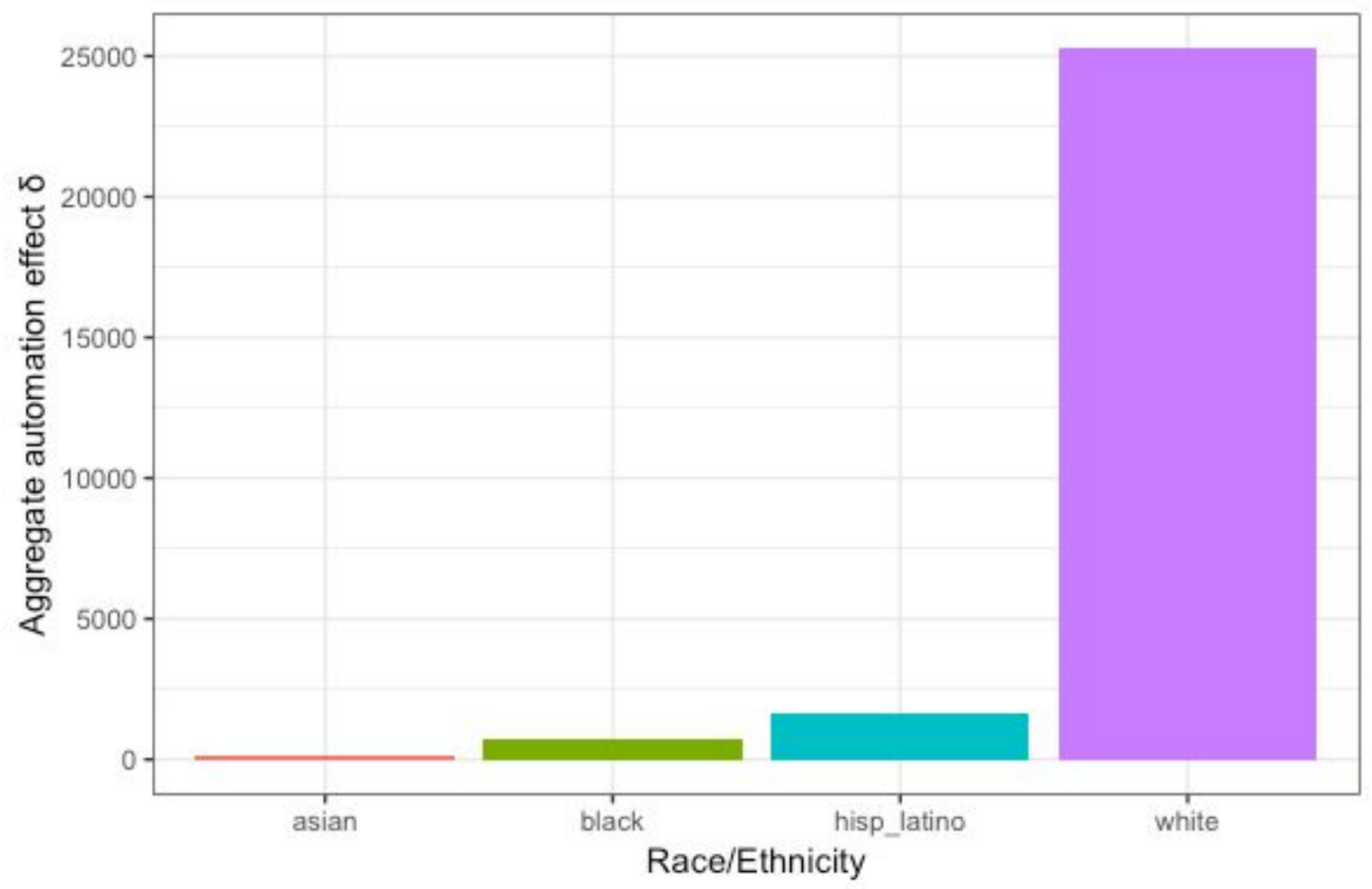

Figure 7. The aggregate effect of automatability on workers by racial and ethnic groups. 
In addition to aggregate effect, I also considered intra-occupational representation. I applied an OLS linear regression to the probability of computerization, controlling for interaction between races. This was then used to calculate predicted values for each demographic based on the proportion of workers for each racial/ethnic group within each occupation. A summary of this model is found in Table 2, and the predicted values are graphically demonstrated in Figure 8. Notably, as the proportion of Black and Hispanic workers increases within an occupation, the occupational automatability is also higher, while the opposite is true White workers, seemingly contradicting the aggregate effect, likely due to the population differences between various occupations. While population is accounted for in the aggregate effect calculation, the predicted values are based on intra-occupational representation.

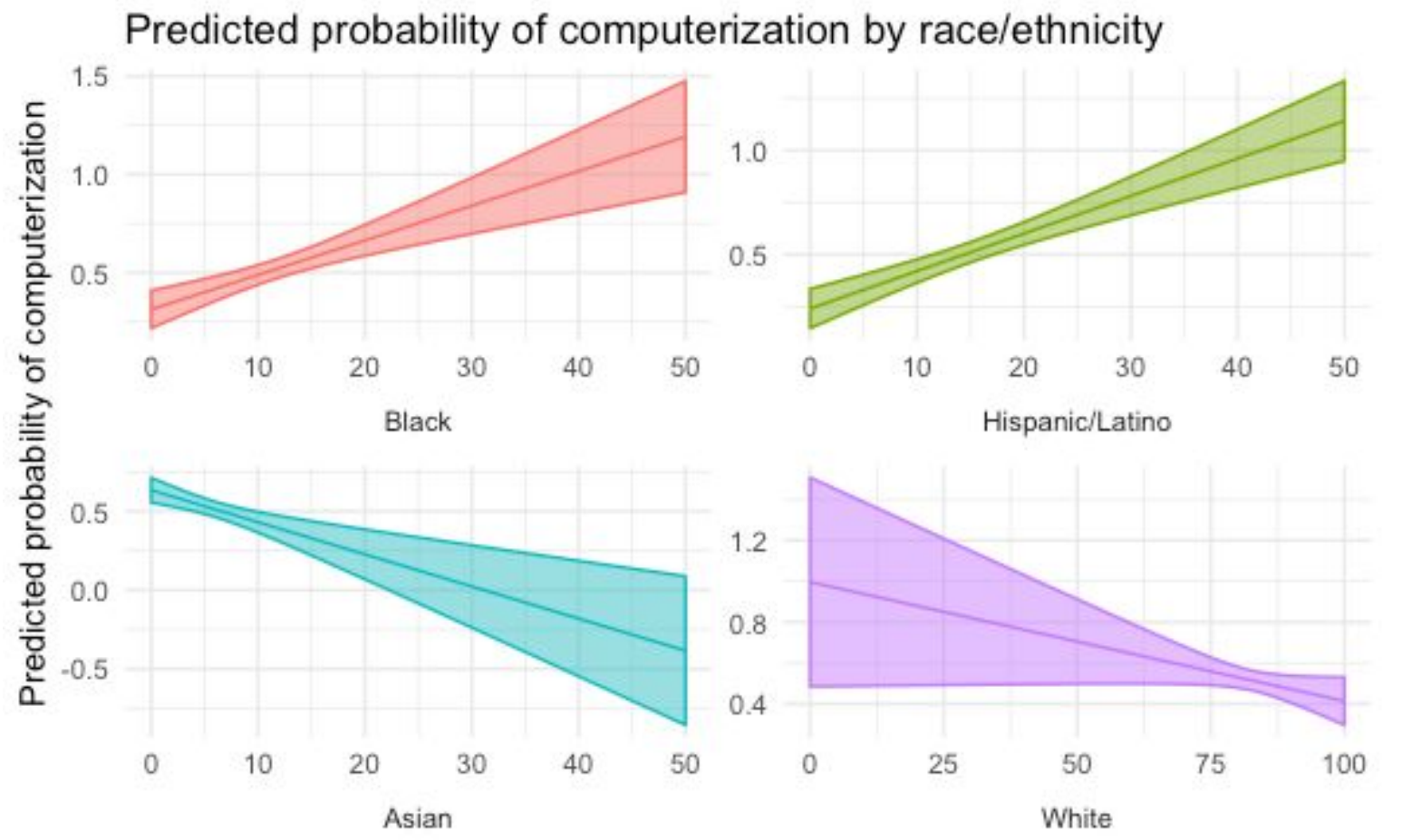

Percent in occupation by race/ethnicity

Figure 8. Predicted values for probability of computerization for each racial and ethnic demographic 
Table 2. Probability of automatability by intra-occupation demographics

\begin{tabular}{|c|c|}
\hline & Dependent variable: \\
\hline & Probability of Automation \\
\hline Pct Occupation & $\begin{array}{c}-0.020^{* * *} \\
(0.005)\end{array}$ \\
\hline Black & $\begin{array}{c}-0.321^{* * *} \\
(0.064)\end{array}$ \\
\hline Latino & $\begin{array}{c}-0.393^{* * *} \\
(0.063)\end{array}$ \\
\hline White & $\begin{array}{c}0.362 \\
(0.263)\end{array}$ \\
\hline Pct Occ:Black & $\begin{array}{c}0.038^{* * *} \\
(0.007)\end{array}$ \\
\hline Pct Occ:Latino & $\begin{array}{c}0.038^{* * *} \\
(0.006)\end{array}$ \\
\hline Pct Occ:White & $\begin{array}{l}0.015^{* *} \\
(0.006)\end{array}$ \\
\hline Constant & $\begin{array}{c}0.634^{* * *} \\
(0.040)\end{array}$ \\
\hline Observations & 848 \\
\hline $\mathrm{R}^{2}$ & 0.091 \\
\hline Adjusted $\mathrm{R}^{2}$ & 0.083 \\
\hline Residual Std. Error & $0.361(\mathrm{df}=840)$ \\
\hline F Statistic & $12.015^{* * *}(\mathrm{df}=7 ; 840)$ \\
\hline
\end{tabular}

\section{Limitations}

Because of the Frey and Osborne model's prevalence and the availability of their data, I make use of the prediction values from their seminal work. Still, the dataset is not without its limitations: The paradigmatic view of automation and work tends to consider susceptibility to automation mainly as a function of automatability. This kind of framework of work and employment tends to consider capital as a perfect substitute for labor and ignore how the political and social context affects the labor market. The prevailing economic models - including the Frey 
and Osborne model applied in this analysis - are then often used to make conclusions about the future of employment, despite assuming perfect labor-capital substitution and excluding non-technological factors. The Obama administration, for instance, drew upon the Frey and Osborne study's automatability findings (namely that $47 \%$ of US jobs were at risk due to automation) to write a report on the future of employment in the U.S. and to call for policy solutions. Likewise, the Frey \& Osborne (2013) data makes predictions broadly based on occupations rather than tasks. Many predictive models are beginning to look to a task-based approach to automation, as technologies tend to replace tasks rather than whole occupations, and may augment or rearrange the labor of existing workers rather than replace them entirely (Autor, 2015).

Furthermore, the probabilities from the Frey and Osborne study were calculated partly through a panel of machine learning researchers subjectively hand-labelling of 70 occupations as either automatable or not, combined with the "objective" O*NET measures described above. Much like the aforementioned automatability vs. susceptibility conflict, this method tends to see occupations as solely a sum of several tasks, and leaves out the importance of humans to the very nature of the work, leading to some intuitively odd conclusions. For instance, fashion models have a 0.98 probability of automation according to their task-based analysis, despite human celebrity and sexuality being intuitively crucial to the occupation. (That said, some firms are already using virtual models to market attire for e-commerce, which is seen as a much more cost-effective and versatile means of displaying products, though not without pushback (see Grundberg \& Molin, 2013).) 


\section{Conclusion}

Labor and race in the United States have historically been and continue to be tightly linked (Cowan, 1997; Roediger, 2007). As described by Roediger (2007), work serves to construct race and reinforce systems of racial stratification, while racial and ethnic demographics can in turn affect the kind of work an individual does. Other variables related to race, like social capital (or the "niches" described in Jones (1998)), policy outcomes (Boswell, 1986), geography (Moretti, 2013), access to education and training (Roscigno, 1998), and discrimination (Cowan, 1997) all affect and complicate who does what work. In this section, I will apply the initial finding that White workers are disproportionately automatable in order to present potential outcomes for race, employment, and the greater social and political context of work.

Autor (2015) argues that workers respond to automation by separating into low-skill non-routine service work and high-skill "abstract" professional work, with middle-skill tasks (particularly involving information processing) being done by technology. Today, Black and Hispanic workers already are disproportionately represented in these low-skill service occupations (Bureau of Labor Statistics, 2016). As such, there are both sociological and political implications for this shift when coupled with the quantitative findings of this study. Sociologically, as Roediger (2007) argues, labor structures can rearrange racial stratification: The possibility of increased White labor in the service sectors is thus a potential force for reinvigorating racial inequality. For instance, in competition for the same low-wage service jobs, Black and Hispanic workers may be pushed out due to other structural disadvantages like lower labor market power (Borowczyk-Martins, Bradley, \& Tarasonis, 2017). Despite White workers being much more affected by occupational automatability in the aggregate, the difficulty of adjusting within the labor market may be much more difficult for non-White workers. 
Apart from the effects on racialized labor broadly, automation can have political outcomes. Frey, Berger, \& Chen (2018) found that labor markets that were more exposed to robot adoption also experienced significantly higher support for Donald Trump in the 2016 presidential election. From a top-down perspective, disproportionate impact on a certain group of workers can affect legislative outcomes. The Chinese Exclusion Act of 1882 and the Trump Administration's recent suspension of the H1-B visa - which tends to bring in high volumes of tech workers from populous countries like India and China - are perhaps two notable examples of policy enacted based on purported job insecurity (Jan, 2017). The rearrangement of labor, then, can have various political implications and policy outcomes that may in turn further susceptibility to automation.

\section{Final Thoughts}

The primary goal of this analysis is to elucidate the differing outcomes of automation on different racial and ethnic groups both throughout American history and in the modern age of AI-driven automation. As a result, this paper also aims to demonstrate the imperative of focusing on the susceptibility of automation as an outcome of multiple different social, political, and technological factors. As exemplified by the period of American industrialization, different groups experience different occupational and employment outcomes depending on the social and political context of automation. These two narratives - the broad predictions regarding economic outcomes in the automation literature, and the analyses of the differing effects of labor displacement for different demographics - must be synthesized in order to more accurately capture the effects of AI-driven automation on different groups of workers.

Future research on automation and employment should consider these non-technical factors both when creating these predictive models and when analyzing the implications of their outcomes. For instance, the interaction between labor market power or wages of a certain group of 
individuals and whether or not their work is automated is still to be explored, despite organized labor historically having crucial negotiating power in the employment outcomes of various groups (Cowan, 1997). Other variables like gender and geography are also worth investigating in order to robustly understand the effects that AI-driven technologies will have on the diverse American workforce. A real-world approach is ultimately necessary to truly bring studies of automation and employment into the 21 st century, and to make this urgent body of research more multidimensional, robust, and accurate. 


\section{Acknowledgements}

"My dear Miss Glory, Robots are not people. They are mechanically more perfect than we are, they have an astounding intellectual capacity, but they have no soul."

$$
\text { - Karel Capek, R.U.R. }
$$

No robot could ever replicate the kindness, patience, and candor of Professors Sergio Garcia-Rios, Karen Levy, and Jamila Michener, who served on the College Scholar committee for this project.

I am forever indebted to Professor Garcia-Rios not only for inspiring this project in his fun and engaging research methods course, but also for keeping me on my toes, for his good humor, and for his constant, tireless support. His vigilance and energy are utterly unmatched, and I can say with certainty that this paper could not have been written without his help.

This project also would not have been possible without Professor Levy, who has served not only as an inspiration to me, but also as a genuine friend and mentor in every sense. Much of this work was inspired by her own prolific research, as well as her courses on surveillance \& privacy and technology \& law. I sing her praises so often that my friends are starting to get annoyed. (But I will never stop!)

From the day I joined the College Scholar program, Professor Michener has listened intently to my ramblings on politics and technology and molded this paper into what it is today. I once told my friends that I often feel most at peace after meeting with her. I owe so much of this project to Professor Michener and her cool groundedness, and I am honored to have been able to learn from her.

I would like to thank Professor Adam Seth Litwin for his advice and limitless knowledge on technology and labor. His (award-winning!) course on technology and work was everything I could have wanted and more. Thank you also to Professor Michael Osborne of Oxford University for providing access to the data from his seminal 2013 work with Professor Carl Frey.

The College Scholar program has provided me with the education of my dreams, and for that I am immensely grateful. Thank you to Dean James Finlay, Professor Michael Goldstein, and Anne Birien for their advising. Thank you especially to my fellow College Scholars Claire Liu and Samuel Barnett for reading and writing and getting distracted with me. I can't wait to see the work they produce.

Thank you to all of my friends who have made every moment of this whole college thing worthwhile. Every day with them has been richer and funnier than the last. I'm not sure what I did in a previous life to deserve them, but I'm glad I did it.

Lastly, thank you to my parents who have remained remarkably composed as I ran with my education like a child holding scissors. I love them with all my heart, and I owe them the world. 


\section{References}

Acemoglu, D., \& Restrepo, P. (2017). Robots and Jobs: Evidence from US Labor Markets (Working Paper No. 23285). National Bureau of Economic Research. https://doi.org/10.3386/w23285

Agiesta, J., \& Tseng, J. (2016, September 29). The anatomy of a white, working-class Trump voter. Retrieved November 26, 2018, from https://www.cnn.com/2016/09/19/politics/trump-supporters-working-class-white-kaiserfamily-foundation-infographic/index.html

Automation Potential and Wages for US Jobs. (2018, October 1). Retrieved December 3, 2018, from https://public.tableau.com/profile/mckinsey.analytics\#!/vizhome/AutomationandUSjobs/ USAutomationlandscape

Autor, D. H., Levy, F., \& Murnane, R. J. (2003). The skill content of recent technological change: An empirical exploration. The Quarterly Journal of Economics, 118(4), 1279-1333.

Borowczyk-Martins, D., Bradley, J., \& Tarasonis, L. (2017). Racial discrimination in the U.S. labor market: Employment and wage differentials by skill. Labour Economics, 49, 106-127. https://doi.org/10.1016/j.labeco.2017.09.007

Boswell, T. E. (1986). A Split Labor Market Analysis of Discrimination Against Chinese Immigrants, 1850-1882. American Sociological Review, 51(3), 352-371. https://doi.org/10.2307/2095307

Brammer, J. P. (2015, September 24). Latinos Are More Than “The Jobs Americans Don't Want To Do." Retrieved December 5, 2018, from https://www.huffingtonpost.com/john-paul-brammer/latinos-are-more-than-the_b_81897 24.html

Brynjolfsson, E., \& McAfee, A. (2016). The Second Machine Age: Work, Progress, and Prosperity in a Time of Brilliant Technologies. New York London: W.W. Norton \& Company.

Card, D., \& DiNardo, J. E. (2002). Skill Biased Technological Change and Rising Wage Inequality: Some Problems and Puzzles (Working Paper No. 8769). National Bureau of Economic Research. https://doi.org/10.3386/w8769

Carnes, N., \& Lupu, N. (2017, June 5). It's time to bust the myth: Most Trump voters were not working class. Retrieved October 29, 2018, from https://www.washingtonpost.com/news/monkey-cage/wp/2017/06/05/its-time-to-bust-t he-myth-most-trump-voters-were-not-working-class/

Cassedy, J. G. (1997, Summer). African Americans and the American Labor Movement. Prologue, 29(2). Retrieved from https://www.archives.gov/publications/prologue/1997/summer/american-labor-movemen t.html

Chew, K., Leach, M., \& Liu, J. M. (2009). The Revolving Door to Gold Mountain: How Chinese Immigrants Got Around U.S. Exclusion and Replenished the Chinese American Labor Pool, 1900-1910. The International Migration Review, 43(2), 410-430.

Chokshi, N. (2018, April 27). Trump Voters Driven by Fear of Losing Status, Not Economic Anxiety, Study Finds. The New York Times. Retrieved from https://www.nytimes.com/2018/04/24/us/politics/trump-economic-anxiety.html

Cowan, R. S. (1997). A social history of American technology. New York: Oxford University Press.

Cox, D., Lienesch, R., \& Jones, R. P. (2017, May 9). Beyond Economics: Fears of Cultural Displacement Pushed the White Working Class to Trump. Retrieved November 26, 2018, from 
https://www.prri.org/research/white-working-class-attitudes-economy-trade-immigration -election-donald-trump/

Crocker, C. (1876-1877). "Testimony before Congress," Report of the Joint Special Committee to Investigate Chinese Immigration, Senate Report No. 689, 44th Congress, 2nd sess.

Elliott, L. (2018, February 1). Robots will take our jobs. We'd better plan now, before it's too late I Larry Elliott. The Guardian. Retrieved from https://www.theguardian.com/commentisfree/2018/feb/01/robots-take-our-jobs-amazongo-seattle

Frey, C. B., Berger, T., \& Chen, C. (2018). Political machinery: did robots swing the 2016 US presidential election? Oxford Review of Economic Policy, 34(3), 418-442. https://doi.org/10.1093/oxrep/gry007

Grundberg, S., \& Molin, A. (2013, January 24). Retailers Conjure Virtual Models. Wall Street Journal. Retrieved from https://www.wsj.com/articles/SB10001424127887323468604578249752619254898

Hoban, B. (2017, August 24). Do immigrants "steal” jobs from American workers? Retrieved December 5, 2018, from https://www.brookings.edu/blog/brookings-now/2017/08/24/do-immigrants-steal-jobs-fr om-american-workers/

Horsey, D. (2017, March 31). Robots, not immigrants, are taking American jobs. Los Angeles Times. Retrieved from http://www.latimes.com/opinion/topoftheticket/la-na-tt-robots-jobs-20170330-story.html Ignatiev, N. (1995). How the Irish became White. New York: Routledge.

Jan, T. (2017, April 3). This one group gets 70 percent of high-skilled foreign worker visas. Retrieved December 5, 2018, from https://www.washingtonpost.com/news/wonk/wp/2017/04/03/this-one-group-gets-70-p ercent-of-high-skilled-foreign-worker-visas/

Jones, J. (1998). American work: four centuries of black and white labor (1st ed). New York: W.W. Norton.

Linton, D. (1991). THE MAKING OF A PARIAH: The Case of the Luddites. ETC: A Review of General Semantics, 48(4), 404-413.

LoBianco, T., \& Killough, A. (2016, August 19). Trump pitches black voters: "What the hell do you have to lose?" Retrieved December 5, 2018, from https://www.cnn.com/2016/08/19/politics/donald-trump-african-american-voters/index. html

Moretti, E. (2013). The new geography of jobs (1. Mariner Books ed). Boston, Mass.: Mariner Books.

Muoio, D. (2017, September 17). RANKED: The 18 companies most likely to get self-driving cars on the road first. Retrieved December 4, 2018, from https://www.businessinsider.com/the-companies-most-likely-to-get-driverless-cars-on-the -road-first-2017-4

Porter, E. (2018, January 20). Where Were Trump's Votes? Where the Jobs Weren't. The New York Times. Retrieved from https://www.nytimes.com/2016/12/13/business/economy/jobs-economy-voters.html

Qiu, L. (2018, October 31). White House Falsely Claims Trump Has Created More Jobs for Black Americans Than Obama Did. The New York Times. Retrieved from https://www.nytimes.com/2018/08/14/us/politics/fact-check-trump-jobs-black-americans .html 
Roediger, D. R. (2007). The wages of whiteness: race and the making of the American working class (Rev. ed). London ; New York: Verso.

Roscigno, V. J. (1998). Race and the Reproduction of Educational Disadvantage. Social Forces, 76(3), 1033-1061. https://doi.org/10.2307/3005702

Sabin, D. (n.d.). Amazon Scary New Robot Model Also Takes Selfies. Retrieved December 4, 2018, from https://www.inverse.com/article/27007-amazon-robot-fashion-model-patent

Schwartz, N. D. (2016, November 29). Trump to Announce Carrier Plant Will Keep Jobs in U.S. The New York Times. Retrieved from https://www.nytimes.com/2016/11/29/business/trump-to-announce-carrier-plant-will-ke ep-jobs-in-us.html

Scruggs, O. M. (1960). Evolution of the Mexican Farm Labor Agreement of 1942. Agricultural History, 34(3), 140-149.

Silver, N. (2016, November 22). Education, Not Income, Predicted Who Would Vote For Trump. Retrieved November 26, 2018, from https://fivethirtyeight.com/features/education-not-income-predicted-who-would-vote-for -trump/

Takaki, R. T. (1989). Strangers from a different shore: a history of Asian Americans (1st ed). Boston: Little, Brown.

Takayama, L., Ju, W., \& Nass, C. (2008). Beyond dirty, dangerous and dull: What everyday people think robots should do. In 2008 3rd ACM/IEEE International Conference on Human-Robot Interaction (HRI) (pp. 25-32). https://doi.org/10.1145/1349822.1349827

Tankersley, J. (2016, November 9). How Trump won: The revenge of working-class whites. Retrieved October 29, 2018, from https://www.washingtonpost.com/news/wonk/wp/2016/11/09/how-trump-won-the-rev enge-of-working-class-whites/

Trotter, J. W. (2000). African Americans and the Industrial Revolution. OAH Magazine of History, 15(1), 19-23.

Vardi, M. Y. (2017, September 1). What the Industrial Revolution really tells us about the future of automation and work. Retrieved December 3, 2018, from http://theconversation.com/what-the-industrial-revolution-really-tells-us-about-the-futur e-of-automation-and-work-82051

Viscelli, S. (2018). Driverless? Autonomous Trucks and the Future of the American Trucker. Center for Labor Research and Education, University of California, Berkeley, and Working Partnerships USA.

Williams, A. (2018, January 20). Will Robots Take Our Children's Jobs? The New York Times. Retrieved from https://www.nytimes.com/2017/12/11/style/robots-jobs-children.html 